GH130 に属する糖質加水分解醰素 $\beta-1,2-$ -

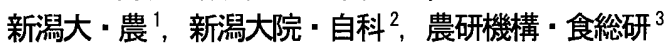

○知久和寛 ${ }^{1}$, 仁平高則 ${ }^{2}$, 鈴木絵里香 ${ }^{2}$, 西本完 ${ }^{3}$, 北岡本光 ${ }^{3}$, 中井博之 ${ }^{1,2}$, 大坪研 $^{1,2}$

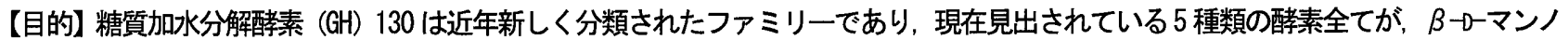
シドの加リン酸分解を触媒し， $\alpha$-Dーマンノース 1 リン酸を生成するホスホリラ一ゼとして特徴付けされている。今回, 分子系統樹解析 によって機能未知グループに分類された Dyadobacter fermentans ATCC 700827 由来のGH130 のホモログタンパク質 (Dfer_3176) に着目 し，その機能解析を行った結果，GH130 において初めての糖質加水分解酵素を見出したので報告する。【方法および結果】大腸菌を宿主 として生産した組換えDfer_3176 タンパク質を用い， $\alpha$-Dーマンノース1リン酸と各種糖受容体とのオリゴ糖合成能を, TLCを用いて調べ た。その結果，いずれの糖受容体に対してもオリゴ糖生産能は認められなかったものの，1,2- $\beta$-マ-マンノビオ一スを含む反応系で D-マ

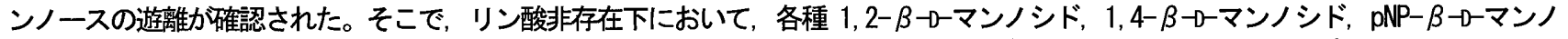
シドに対する加水分解能を調べた結果， 1，2- $\beta$-Dーオリゴマンナンのみに加水分解活性が認められた。さらに，重合度 $2 \sim 4$ の $1,2-\beta-D-$ オリゴマンナンに対する反応速度論的解析により，1，2- $\beta$-Dーマンノテトラオースを最も良い基質にすることを明らかにした。また，

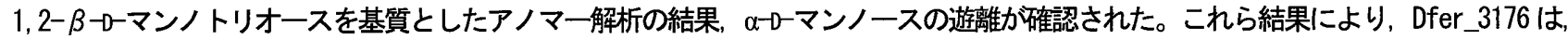

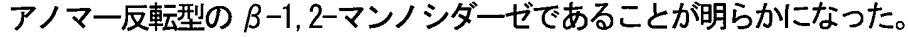

\title{
C-13* 新規ホスホリラ一ゼを用いたセロビオン酸の合成
}

新潟大院・自然科学 ${ }^{1}$, 新潟大 $\cdot$ 農 $^{2}$, 農研機構・食総研 ${ }^{3}$

O斉藤由華 ${ }^{1}$, 仁平高則 ${ }^{2}$, 西本 完 $^{3}$, 北岡本光 ${ }^{3}$, 中井博之 ${ }^{1,2}$, 大坪研 ${ }^{1,2}$

【目的】ホスホリラ一ゼは，厳密な基質特異性と反応の可逆性から，オリゴ糖合成に有効な触媒の一つである。しかし既知ホスホリラー

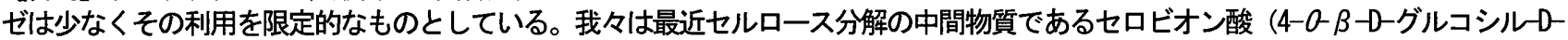
グルコース）を特異的に加リン酸分解する新規酵素セロビオン酸ホスホリラ一ゼを発見した。本報では, 安価なスクロ一スとグルコン酸 を出発材料とし，スクロースホスホリラ一ゼおよびセロビオン酸ホスホリラ一ゼによるセロビオン酸の合成方法の構築を行なった。

【方法および結果】スクロースホスホリラ一ゼおよびセロビオン酸ホスホリラ一ゼは, 大腸菌を用いた組換え酔素として調製した。500 mM スクロース，500 mM グルコン酸を出発材料とし， $10 \mathrm{mM}$ 無機リン酸，スクロースホスホリラーゼ $(0.4 \mathrm{U} / \mathrm{mL})$ ，セロビオン酸ホスホリラ 一ゼ $(2 \mathrm{U} / \mathrm{mL})$ を混合しワンポット酵素反応を行なった。この生産システムでは, スクロ一スホスホリラ一ゼの加リン酸分解反応によ リスクロースから $\alpha$-グルコース 1-リン酸を遊離させ，これとグルコン酸をセロビオン酸ホスホリラ一ゼの基質として利用することで セロビオン酸を生産する。経時的にサンプリングした結果, 出発材料のスクロースの消費およびセロビオン酸の生産か確認された。ま



\section{Cp-14* GH94 セロビオン酸ホスホリラーゼの基質特異性の構造基盤}

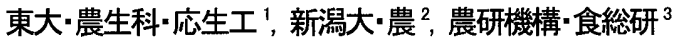

ONam Young-Woo', 仁平高則 ${ }^{2}$, 北岡本光 ${ }^{3}$, 中井博之 ${ }^{2}$, 荒川孝俊 ${ }^{1}$, 伏信進矢 ${ }^{1}$

【目的】近年、セルロ一スの加水分解に加えて酸化分解が注目されているが、その主な最終産物であるセロビオン酸の代謝経路について は不明であった。我々はごく最近、多糖分解性海洋細菌 Saccharophagus degradans より新規酵素セロビオン酸ホスホリラーゼ(CBAP) を発見した。CBAPはGH94 に属し、セロビオン酸を加リン酸分解した産物（グルコース1ーリン酸とグルコン酸）か下流の代謝経路に繋が ることか明らがなっている。本研究では $\mathcal{S}$. degradans 由来CBAP のX 線結晶構造解析を行い、その基質認識と反応機構を解明すること を目的とした。

【方法】大腸菌を用いて CBAP を発現させ、精製タンパク質を用いて結晶を作成した。KEK-PF でX線回折を測定し、Se-SAD 法により構造 を決定した。セロビオン酸とグルコン酸を結晶にソ一キングし、複合体の立体構造を決定した。さらに、受容体基質にグルクロン酸を用 いて合成される産物 GIc- $\beta 1,3-$ GI CUA との複合体の構造も決定した。

【結果】CBAP の全体構造は他の GH94 酵素と同様に2つのドメインからなる。GH94 のサブサイト-1 は保存性が高いが、CBAP のサブサイ ト+1 はグルコン酸に特異的なユニ一クな構造を取っていた。特に、グルコン酸とセロビオン酸のカルボキシル基の認識には Arg609 と Lys613 が関わっていることが明らかとなったが、GIc- $31,3-G \mid c U A$ の複合体においては、グルクロン酸部分は環状構造をとっており、そ のカルボキシル基の認識にはこれらの残基は関わっていなかった。

\section{$\mathrm{Cp}-15^{*}$}

Bacteroides thetaiotaomicron由来L-フコキナーゼ/GDP-Lーフコースピロホスホリラーゼの機能解析

農研機構食品総合研究所 ${ }^{1}$

○劉 遠 ${ }^{1}$, 仁平高則 ${ }^{1}$, 西本 完 $^{1}$, 北岡本光 ${ }^{1}$

【目的】しーフコキナ一ゼ/GDP-しーフコースピロホスホリラーゼは一本のペプチドに二つのドメインが同居している二重触媒酵素である。 本酵素は、様々な生物のサルベージ経路に存在していることが報告されている。我々は腸内細菌 Bacteroides thetaiotaomicron のゲノ ムから本酵素をコ一ドする遺伝子 (Btfkp) を新規取得し、大腸菌を宿主とする異種タンパク質発現系で組換え Btfkp を生産させ、その 詳細な機能解析を行った。

【方法】C 末端にHis-tag を付加させた組換えBtfkp fをNi-NTA カラムにより精製した。組換え Btfkp の機能解析は、Lーフコ一スと ATP を基質とした Lーフコキナーゼ活性及びLーフコース 1-リン酸とGTP を基質としたGDP-Lーフコースピロホスホリラーゼ活性の速度論的評価 を行った。

【結果】速度論的解析より、組換え Btfkp はSequential BiBi 型䤉素であることが判明した。さらに、本酵素の金属イオン要求性に着目 したところ、Lーフコキナ一ゼ活性では、 $\mathrm{Mn}^{2+}$ 存在下におおける kat はマグネシウム $\mathrm{Mg}^{2+}$ 存在下の 4 倍だったのに対し、GDP-Lーフコースピロ ホスホリラーゼ活性では、 $\mathrm{Mn}^{2+}$ 存在下における $k$ cat $は \mathrm{Mg}^{2+}$ 存在下の $1 / 2$ 程度だった。

本研究は「農林水産業・食品産業推進事業」により行われた。 